Vol. 3, n 1 | 1999

Varia

\title{
A typology of nineteenth-century police
}

\section{Clive Emsley}

\section{OpenEdition \\ Journals}

Electronic version

URL: https://journals.openedition.org/chs/934

DOI: $10.4000 /$ chs.934

ISSN: 1663-4837

\section{Publisher}

Librairie Droz

\section{Printed version}

Date of publication: 1 January 1999

Number of pages: $29-44$

ISBN: 2-600-00356-8

ISSN: 1422-0857

\section{Electronic reference}

Clive Emsley, "A typology of nineteenth-century police", Crime, Histoire \& Sociétés / Crime, History \& Societies [Online], Vol. 3, $n^{\circ} 1$ | 1999, Online since 03 April 2009, connection on 22 March 2022. URL: http://journals.openedition.org/chs/934 ; DOl: https://doi.org/10.4000/chs.934

(c) Droz 


\title{
A typology of nineteenth-century police
}

\author{
Clive Emsley'
}

Taking as its starting points the Bobby in Victorian England and some of the general conclusions of David H. Bayley's comparative work, this essay suggests that three basic types of police developed in nineteenth-century Europe. Focussing primarily on England, France, Italy and Prussia it argues that, in terms of accountability, control and form, state civilian, state military, and civilian municipal police can be delineated as Weberian ideal types. Individual states did not necessarily develop all three types; but everywhere governments sought to learn and/or borrow from the police system and pratice of their neighbours, central governments were generally in negotiation with local government over policing matters, and were otherwise constrained by traditions and finance. The essay concludes by posing some very general questions for future work regarding police autonomy and police violence.

Le présent essai, prenant pour point de départ l'exemple du «Bobby» de l'Angleterre victorienne et certaines conclusions générales des recherches comparatives de David H. Bayley, défend l'idée que l'Europe du XIX' siècle a $v u$ se développer trois modèles fondamentaux de police, que l'on peut construire comme des types-idéaux weberiens, en fonction de l'autorité compétente, de la manière dont la police est contrôlée et ses formes d'organisation. En examinant en particulier, les cas anglais, français, italien et prussien, on peut ainsi identifier un type "police d'État civile», un type «police d'État militaire» et un type «police civile municipale». Ces trois types ne sont pas nécessairement présents dans chaque État, mais les gouvernements se sont partout inspirés des systèmes policiers et des pratiques de leurs voisins ; partout les gouvernements centraux ont dû négocier les questions de police avec les autorités locales et leur action a été limitée par des contraintes financières ou des traditions. En conclusion, cet essai esquisse des orientations pour de futures recherches touchant à l'autonomie et à la violence policières.

1 Clive Emsley is Professor of History at the Open University, U.K., and co-director of the European Centre for the Study of Policing there. Since 1995 he has been President of the International Association for the History of Crime and Criminal Justice. His publications include: Policing and its Context, 1750-1870 (1983), Crime and Society in England 1750-1900 (2 ${ }^{\text {nd }}$ edn. 1996) and The English Police: a Political and Social History (2 ${ }^{\text {nd }}$ edn. 1996). He is currently completing a comparative study of the development of Gendarmerie-style policing in nineteenth-century Europe. 
$V^{1}$ ictorian Englishmen were proud of their police and praised the British model, civilian, restrained, free from corruption, as superior to a generalised European model, military, arbitrary, political, secretive. Quite simply, theirs was 'the best police in the world"2. Yet it was Charles Reith, writing in the mid-twentieth century, who best encapsulated what remains the traditional view of police development in Britain ${ }^{3}$. Reith, following the assertions of nineteenth-century police reformers like Edwin Chadwick, believed that the pre-police system of parish constables and night watchmen was inefficient and incapable of dealing with the problems of rising crime and increasing disorder that he considered to have emerged in the late eighteenth and early nineteenth centuries with burgeoning urban growth and industrialisation. Fortunately, a group of far-sighted reformers, including Chadwick, came up with the solution - the modern police. First established in London in 1829, the 'police idea' rapidly showed its worth, was adopted across the whole country, and was perceived as a model by others elsewhere. The logic and simplicity of Reith's explanation accounts for its longevity. It remains a useful straw man for academics to begin critical assessments of police development - though some, having nuanced his interpretation, describe their conclusions as neoReithian ${ }^{4}$. Unnuanced, it remains the version deployed by the police themselves when they address their own history, particularly in the form of official histories ${ }^{5}$.

The importance of the Metropolitan Police was explicit in Reith's work; the superiority of the British model was generally implicit. However in The Blind Eye of History he differentiated between two kinds of police:

The kin police or Anglo-Saxon police system, and the ruler appointed gendarmerie, or despotic totalitarian police system. The first represents, basically, force exercised indirectly by the people, from below, upwards. The other represents force exercised, by authority, from above, downwards.

Kin police were democratic; gendarmeries were not. It was therefore 'unnecessary to look far beyond this fact to account for the comparative failure of democracy elsewhere than in Britain and the United States'. This probably tells us more about Reith, the son of a Victorian doctor and a man who had been a tea and rubber planter and an officer in the Indian army, than it does about police systems in genera ${ }^{6}$. It also underlines, perhaps, a long-standing suspicion and ignorance of things European within British society more colourfully expressed by one of the central characters of the popular1980s television series Minder, the entrepreneurial rogue Arthur Daley, for whom Europe meant "plods with pistols, iffy food, and sawn-off toilets"7.

2 See, for example, Pike (1873-1876, ii, p. 457 and 461); and for other comments on the superiority of the English police at the turn of the century see Emsley (1992).

3 Reith $(1938,1940,1943,1948,1952)$.

4 Reiner (1985, p. 47).

5 A good example is Ascoli (1979).

6 Reith (1952, p. 20 and 244); for Reith himself see Hjellemo (1977).

7 Minder on the Orient Express, Euston Films, 1986. My thanks to Dr. Jill Stevenson of the University of Edinburgh for reminding me of this wonderful Eurosceptic phrase. 'Plod' is pejorative slang for the ordinary constable who walks (or 'plods') his beat. The term has acquired an additional element 
There have never been two clear models of police, a British one, also employed in the British Empire and the United States, and a European one. Indeed, until the 1960 s at least, it would be difficult to define a single British model. While in contemporary France and Italy apologists for the situation of having two major and very different police forces, one military the other civilian, functioning side-by-side - the Gendarmerie nationale and the Police nationale in the former, the Carabinieri and the Polizia di Stato in the latter ${ }^{8}$ - confidently declare this to be good for democracy since the two balance each other and consequently impede any attempt by a single faction to seize power in a coup.

David Bayley's comparative investigation of police development in Britain, France, Germany and Italy starts with a contemporary baseline of the police as they are (or rather were in 1975) and then explores how the present came to be ${ }^{9}$. He draws attention to significant differences in the contemporary systems, pinpoints the key period of development as beginning in the late seventeenth century, though the main focus is on the nineteenth, but stresses how the different police systems really emerged at different times. He suggests that distinctive national features within the different police forces have remained remarkably constant through a multiplicity of upheavals. He denies that the growth of crime, industrialisation, population, or urbanisation have been especially significant in the development of these police forces; much more important was the transformation of the organisation of political power, the extent of violent popular resistance to government, the erosion of the old social bases of community authority, and the creation of new law and order tasks. There is much that is stimulating and significant in this essay, but at times it is also so general as not to explain very much in terms of specific historical development. In particular, while he suggests that the forms of policing are to be explained by prior practices, he never explores the longevity of the old social structures and of traditional policing; and at times he appears to assume a degree of national organisation which, the following discussion will argue, did not exist. While he notes that the Italian Carabinieri was based on the French Gendarmerie, he generally ignores the importance of cultural exchange and the borrowing and subsequent reshaping of police models; something which again will be stressed in what follows.

In a subsequent book Bayley develops an important and thought-provoking typology of contemporary policing based on two dimensions of analysis: the centralisation of command and the number of commands. These, he notes, are often confused because of imprecise use of the concepts of centralisation and decentralisation. "The point is that decentralization creates multiple forces, but multiple forces are not always decentralized'. Thus, for example, countries like France and Italy with multiple forces in fact have centralised command in as much as control is exercised from the capital cities over both the civilian and the para-military police. The key factor in explaining initial centralisation was the scale of violent resistance to the state's assertion of authority and consolidation. The ultimate structure of policing depended on political settlements and resulting traditions, together with the

from the fact that 'Mr. Plod' was the name given (apparently without any pejorative intent) to the policeman in the Toytown of Enid Blyton's popular children's character, Noddy.

8 In Italy there are also the para-military Guardia di Finanza, which claims to have originated in 1774 and which has responsibility for the policing of taxation laws, custorns and excise, and frontier surveillance, and the vigili urbani which largely supervise municipal traffic regulation. 
nature of government. But; at the same time, he warns that 'policing structures should not be read as a symptom of governmental character, therefore identical command structures can accomodate regimes of vastly different types' ${ }^{10}$.

This essay will follow a rather different tack from Bayley; it will tend to amplify some of his conclusions, particularly in demonstrating the degree of negotiation between states and other social actors over police development during the nineteenth century. However, rather than working back from the present, it will focus initially on the police institutions of two European nation states during the nineteenth century. These states, Britain and France, are important in the history of police development: the former because historians of its police have insisted that it was the home of the 'new police', and, during the nineteenth century, many European liberals, as well as police reformers in the United States, professed, or at least aspired, to follow this model; the latter because of the precocity of its development of police institutions which can be seen emerging in their nineteenthcentury, if not their modern, form towards the end of the seventeenth century. From this initial survey it will be suggested that three distinct types of police can be perceived in the two states. It will be suggested further that these types can be found elsewhere and that a recognition of these types contributes to our understanding of the growth of nineteenth-century states and the extent of their internal authority.

\section{II}

In the middle of the nineteenth century there were three distinct models of what can be termed public as opposed to private ${ }^{11}$ policing in the British Isles: those of the Metropolitan Police, the provincial police, and the Irish police ${ }^{12}$. The Metropolitan Police, the first of the 'new police', was commanded by commissioners appointed by central government and was accountable to the home secretary. This dependence on central government was greatly resented by many local authorities in London during the 1830s. They complained that while they were required to pay for the police, they had no say in its management and its operations. Some could point to the fact that under the new police the streets of their district were less well patrolled than they had been with the former night watches. Such protests declined in the middle years of the century, but resurfaced during the debates over the creation of the London County Council during the late 1880 s, and again during the twentieth century.

Provincial police in Britain often drew on the Metropolitan Police for their officer cadres, but some looked elsewhere too, notably to Ireland. They also looked to the Metropolitan system for organisational patterns and operational behaviour. But, unlike the Metropolitan Police, the provincial police, whether borough or county forces, were accountable to local government. There were differences. The

10 Bayley (1985, p. 53 and 71).

11 I make this differentiation between public and private policing largely to avoid the additional category of private police which, in England, could range from gamekeepers on a gentleman's estate to the uniformed constables of the railway companies - the latter not greatly dissimilar from the public police. Such private police could also be found across nineteenth-century Europe and merit their own structural typology from which to analyse comparisons and contrasts.

The following discussion is based on Emsley (1996). 
chief constables of the counties tended to have much greater independence from their police committees than the head constables of boroughs where, in some places, the police continued to be regarded as municipal servants carrying out a variety of administrative functions until well into the twentieth century. The municipal police showed as much evolution in their links with existing forms of local government as they did revolution in their hierarchical structures, uniforms and operational behaviour. The example of London provided a degree of uniformity. The creation of Her Majesty's Inspectorate of Constabulary in 1856 whose certificates of efficiency led to treasury grants, and the subsequent growth of police experts within the Home Office, who preferred to by-pass civilian police committees and speak directly to the experts who served as chief or head constables, generated further uniformity and a degree of centralisation before the First World War. The latter process was assisted by the way in which many police committees began, increasingly, to leave the management of their local police to their chief or head constable. But if police committees, especially urban watch committees which sometimes met weekly and in a few instances even more often, wanted their constables to wear green uniforms as opposed to the usual blue, to collect market tolls, act as municipal mace bearers or mortuary attendants, or in any other local government function, there was nothing to prevent them.

Much of the tight linkage between the police and local government was a result of the way in which the latter had developed and maintained its independence since the Glorious Revolution of 1688. As magistrates, members of local elites ran the counties and boroughs with little direction from the centre; M.P.s and ministers had commonly served as county magistrates, or, as the nineteenth century wore on, as municipal leaders. Moreover, while the machinery of local government had creaked under the pressure of the Revolutionary and Napoleonic wars and during their turbulent aftermath, English magistrates had rarely lost their nerve and popular disorder had never seriously threatened the stability of the state. In Ireland, in contrast, while the gentry saw themselves as similar to their English cousins, they had consistently failed when confronted with disorder in the late eighteenth and early nineteenth centuries. Small wonder then that policing should be taken out of their hands by central government. Dublin was given a Metropolitan Police akin to that in London, while provincial Ireland was given a paramilitary police, the Irish (from 1867, the Royal Irish) Constabulary. The RIC was equipped with firearms; it was stationed in small barracks on main roads and in the principal towns, and it was employed to coerce the recalcitrant peasantry. However, while much Irish history has been written from the perspective of famine, evictions, land war, and general disorder, it appears that, towards the end of the century, the RIC was increasingly accepted within the communities where it served and that it was 'domesticated,' losing much of its military edge - one reason, it can be argued, for its poor showing in the troubles which accompanied the end of World War One ${ }^{13}$.

Mid-nineteenth-century France also had three distinct types of police. In Paris the Prefect of Police, a government appointee, directed the city police. In many respects this police was a much older institution than that of London - the post of Lieutenant Général, the precursor of the Prefect, had been created in 1667; in other

13 Lowe and Malcom (1992). For the origins of the RIC, compared with police development in England, see Palmer (1989). 
respects it had emerged at roughly the same time - in 1829 Prefect Louis Debelleyme had established the sergents de ville as a civilian patrol to restore confidence in the police after a series of scandals, and to help establish his idea of a paternal institution which would ensure «Safety by day and night, free and easy movement of traffic, cleanliness of the public streets, supervision and precautions against any cause of accident, the maintenance of public order in public places, the investigation of offences and the pursuit of offenders $»^{14}$.

A succession of laws during the Revolutionary years established the post of commissaire de police in towns with a population in excess of 5000 . Initially the post was elected, but the reassertion of central government authority under Napoleon saw the commissaire become a government appointee selected from a short-list presented by the departmental prefect. In many instances for at least the first third of the century, men on the short-list were local, sometimes former soldiers, and sometimes men seeking a new government position for a new stage of their career in the emergent state bureaucracy. However, as the century progressed, the men began to see themselves more and more as a professional policemen with a bureaucratic career progressing to bigger towns with more responsiblity, possibly ending as the commissaire central in a large town with several junior, subordinate commissaires. The Journal des commissaires de police first published in January 1853 with the agreement of the minister of the interior, provided the men with a digest of legislation but also contained articles designed to instill them with a sense of mission and the value of their role. But the commissaires provided only a framework of centralised policing. Beneath them were the local police officers inspecteurs, agents de police, sergents de ville - who, for much of the century were dependent upon the municipality for appointment and pay. There was recurrant friction between central and local authority over the appointment of these functionaries. Legislation of 1864 authorised the departmental prefect to nominate the police on the recommendation of the mayor; legislation of 1884 confirmed the mayor as the nominal chief of police, and authorised him to appoint personnel with the agreement of the prefect. There could be conflict between central and local government over policing matters, and this could create difficulties when a commissaire found himself receiving advice and directives from a government in Paris of a very different political hue to the municipality. However, in many places it appears that the municipality increasingly withdrew from direct involvement in the administration of the police leaving matters to the commissaire ${ }^{15}$.

14 «La sûreté, le jour et la nuit, la circulation libre et commode, la propreté de la voie publique, la surveillance et les précautions contre toute cause d'accident, le maintien de l'ordre dans les lieux publics, la recherche des délits et de leurs auteurs»; quoted by Tulard (1976, p. 436-437). Bayley $(1985$, p. 67) argues that, as a result of the Fronde, Louis XIII and Richelieu concluded that regional nobles could not be trusted with government authority, consequently intendants, later assisted by lieutenants general of police, were appointed by the king to impose order as Paris required. This would seem to be one of the instances where Bayley slightly misunderstands the degree of development and institution achieved by the state. While there is, a yet, no detailed study of provincial lieutenants general under the old regime, the posts were venal and it appears that they were often purchased by local seigneurs or other authorities. The monarch was not able to get such individuals, or corporate bodies to enforce order as he required. Local bishops purchased the offices in Beauvais, Reims and St. Malo; the bailliage courts purchased them in Blois and Troyes; see Emsley (1983, p. 19). 
The legislation which first established the commissaires in 1791 brought uniformity to the towns where, under the old regime, a multitude of different individuals and corporations had held police powers, often with overlapping jurisdictions. In the same year the Loi relative à la police rurale of 6 October authorised local communes, if they so wished, to appoint and pay, under the mayor's supervision, a garde champêtre. The law largely formalised a much older practice of appointing field guards, particularly at harvest time; the subsistance crisis of 1795 saw the requirement of appointing a garde champêtre made obligatory, though many communes appear to have ignored it, not the least because of a reluctance to impose a tax on the local community to pay the men. There were a succession of proposals to improve the gardes, by recruiting them from old soldiers, brigading them, making them auxiliaries of the Gendarmerie. During the Napoleonic period some men behaved courageously, often at risk to themselves and their families, in arresting deserters, refractory conscripts, and poachers ${ }^{16}$. Yet the gardes have generally received a bad press, criticised as creatures of the local mayors or large landowners, and/or too susceptible to community opinion. It is worth noting that criticism of them seems gradually to disappear from the monthly and annual reports of the Gendarmerie in the mid-nineteenth century ${ }^{17}$. Perhaps this is indicative of a degree of improvement, though there were still adverse comments from some regions «The service of the gardes champetres is the only one in the department wich leads much to be desired, the reason being that there are too few of them and most of these are incapable ${ }^{18}$. As a group the gardes champêtres await serious academic investigation ${ }^{19}$.

The Gendarmerie nationale was a military body. Reformed and reorganised from the military police of the old regime, the Maréchaussée, it was composed of former regular soldiers, usually NCOs with good conduct records and who had transferred to the corps often, it seems, as a way of continuing in their chosen profession in their pays natal. One of the principal tasks of the Maréchaussée had been keeping the roads safe for travellers and the mail coaches. The Gendarmerie continued with this role. Brigades of six men, though often reduced by shortages or particular exigencies to only four or five, were stationed in barracks in towns and villages along the main roads. They were also expected to provide coercive support for other state functionaries as and when required, to bring in the conscripts, protect tax and ammunition convoys, supervise troops on the march, and to repport on and investigate offences.

Setting the British and French examples side-by-side a broad typology of three kinds of public police can be delineated. The police of metropolitan London and of Paris, both commanded by government appointees and quite independent of local

16 For attacks on the gardes see d'Hauterive (1922-1964, ii, nos. 1378 and 1473, iii, nos. 58, 427 and 726 ), and for a general discussion of their development during the revolutionary and Napoleonic period, see Woloch (1994 p. 156-63).

17 Based on a reading of the Gendarmerie reports of Eure-et-Loir, Finistère, Gers, Nord, Puy-de-Dôme, and Rhône in Archives Nationales, Paris, series $F^{?}$.

18 «Le service des gardes champêtres est le seul du département qui laisse beaucoup à désirer, à raison du trop petit nombre de ces agents et de l'incapacité de la plupart d'entr'eux $\gg$. Service Historique de l'Armée de terre, Vincennes, $G^{8} 180$, Rapport du préfet de l'Allier, 9 July 1859 . See also Santucci (1986, p. 23) and Soulet (1987, p. 286).

19 What promises to be significant research in this area has recently commenced, see Gaveau (1997). 
authority, can be considered as state civilian forces. The borough and county police in Britain, and the urban police and gardes champetres in France all constitute civilian municipal police; men recruited locally and largely under local control though, in both countries such control was gradually being yielded into the hands of 'experts'. It is something of a paradox that, in spite of the reputation which the nineteenth-century French state had for centralisation and a burgeoning bureaucracy, it appears to have lagged behind the British state, so often lauded for its policies of laissez-faire, in the central financing and inspection of such civilianmunicipal police. The third variety of police, represented by the Gendarmerie and the Royal Irish Constabulary, were armed and equipped like soldiers, stationed in barracks, and responsible to a central government ministry; they can conveniently be labelled state military.

State civilian, municipal civilian, and state military are ideal types in the Weberian sense. When different forces are put under the microscope the edges between the distinctions can become decidedly fuzzy. Most nineteenth-century civilian police, for example, had military elements. London's Metropolitan Police may have been given top hats and blue, swallow-tail coats so as not to appear to be soldiers, but the force was rigidly hierarchical and strictly regimented. Furthermore, in the civilian English police, there were large numbers of recruits with military experience and some chief constables, especially those who had held military rank themselves, favoured former soldiers as policemen ${ }^{20}$. The gardiens de la paix, as the patrolmen of the Paris police came to be termed in the second half of the nineteenthcentury, may have been essentially civilian and Napoleon III's reform of them sought to introduce a variety of practices learned from the London Bobby, but threequarters of the vacancies were reserved for former soldiers ${ }^{21}$. Municipal civilian police might receive part of their pay from state funds, and a few of this type, especially among the gardes champêtres could shade into private police - in the sense of gamekeepers and private watchmen - given the patronage systems under which they were recruited and under which they worked. Nevertheless, state civilian, municipal civilian and state military, are sufficiently distinctive types in the ways that the chains of command and accountability functioned, and that men were recruited, equipped and deployed.

\section{III}

Adjusting the focus to look further across nineteenth-century Europe, these same three types can be seen functioning, often side-by-side, in other states. In the Netherlands, for example, there was the Koninklije Marechaussee, a state military police mainly responsible for policing the south and east of the country and answerable primarily to the ministry of war, the Rijksveldwacht, a state civilian police under the ministry of justice, and municipal civilian police in the shape of the Gemeentepolitie of the towns and the Gemeenteveldwachtes of the rural districts.

20 Emsley (1996, p. 193-197).

21 The intention was to encourage men to stay in the army after the initial period of conscription thus laws of 1872, 1889, and 1905 guaranteed civilian posts for veterans after their anmy service, though many expressed their reservations about the quality of the men thus recruited. Berliere (1993, p. 130138). 
From independence in 1830 Belgium had a Gendarmerie nationale, communal police regulated by the municipalities, and very gradually set about developing a state civilian force.

Across much of continental Europe, and particularly in the centre and east, state civilian police grew out of the ideas surrounding what Marc Raeff called 'the wellordered police state'. Raeff appears to suggest that the ordinances passed by German and Russian princes from the seventeenth century, in themselves played a key role in shaping the attitudes of those princes' subjects. Yet it was one thing to pass ordinances and quite another to ensure their implementation. During the Enlightenment Habsburgs, Hohenzollerns and Romanovs developed structures to enforce notions of good 'police' in the broad definition of the term, that is structures that provided a degree of welfare, security, fairness in, and the smooth-running of, markets, together with the maintenance of order. These structures also sought to repress threats against the prince and to keep under surveillance those individuals considered likely to foment trouble. The organisation working under the lieutenant general of police in Paris provided one model here, though such developments would seem to be as much rooted in German traditions as any French model ${ }^{22}$.

State military police, however, were firmly rooted in a French model ${ }^{23}$. French expansion across Europe during the revolutionary and Napoleonic period brought with it Gendarmerie-style policing. The Gendarmes policed the French armies on the march; and where the French settled they proved themselves in fighting brigands, protecting tax convoys and mail coaches, and bringing in the conscripts. Princes, like those of Bavaria and Württemberg, who for much of the first decade of the nineteenth century were under Napoleonic protection began to develop state military police during these years. The Prussian reformers, reeling from the shocks of Jena and Napoleonic dismemberment, sought to create a similar corps as part of their modernisation of the state. On Napoleon's fall princes restored to territories which had been part of his empire, like Vittorio Emanuele I in Piedmont and Cardinal Consalvi in the Papal States, similarly recreated gendarmeries. There were slightly different reasons underlying each case, but the state military police were seen as providing an efficient means of bringing the state to the countryside and cementing its claim to be the sole repository of law and the maintenance of order, of replacing the traditional authority of the seigneur and his agents, and of providing central government with eyes and ears as well as a first line of defence against rural disorder. The initial wave of these gendarmerie creations came in those states which had either been part of the Napoleonic empire or strongly influenced by it - northern and central Italy, the low countries, the lands of the Confederation of the Rhine and Prussia. The second wave came in the aftermath of serious revolutionary disorders - in Spain in 1844, and in the Austrian Empire in 1849.

Well into the nineteenth century, across most of Europe, municipalities were generally responsible for their own policing arrangements. When the British parliament passed its Municipal Corporations Act in 1835 requiring the new town councils to establish watch committees who would be responsible for police organisations, it was following the tradition of leaving such responsibilities to the locality. Similarly the legislation of 1839 and 1840 permitting the creation of county

22 Raeff (1983); Axtmann (1992).

23 Clive Emsley, Gendarmes and the State in Nineteenth-Century Europe, 1999. 
constabularies, left decisions and management to the recognised organ of county government - the bench of county magistrates. The early stages of the French Revolution were strongly marked with notions of devolving powers to the localities: the Gendarmerie may have been nationale, yet it was, initially, to be under the administration of the départements; commissaires, as noted earlier, were, initially, to be elected, and what kind of policing arrangements existed under the commissaire, were to be left to the municipality. While the Gendarmerie and the commissaires were brought under state control within a decade, the ordinary agents de police were not. A rather more detailed glance at the patterns of policing in Italy and Prussia will show how similar complexities were allowed to develop and to continue elsewhere throughout the nineteenth century.

Until the arrival of the French revolutionary armies during the late 1790s, policing in the Italian states was in the hands of armed men (sbirri) who were generally regarded as little better than the brigands they were supposed to combat; indeed, according to a French traveller, Charles Dupaty: «The sbirri are privileged brigands who make war on the brigands who lack privileges». Such research as has been conducted recently on the sbirri has done nothing to contradict such assessments ${ }^{24}$. The French imposed their system of commissaires, gardes champêtres, and gendarmerie across the peninsula, and even the most reactionary of the states restored after Napoleon's fall maintained aspects of the French system. Piedmont was the state which eventually unified Italy and here Vittorio Emanuele I, restored to his northern capital of Turin in May 1814, resolved to turn the clock back to the old regime and abolish everything French. Yet in June 1814 he established the Carabinieri Reali modelled on the French Gendarmerie. Piedmont was a state which prided itself on its military prowess and, consequently, the creation of a state military police by the restored regime was in the traditions of the old regime - and there had been an experiment with an anti-brigand corps of light troops in 1791 - as well as drawing on the new. In the wake of the revolutions of 1848 and the growth of liberal ideology among the rulers of Piedmont a state civilian force was created, this time apparently looking to the new English model. In July 1852 the Piedmontese Parliament passed law 1404 establishing the Guardia di Pubblica Sicurezza for the principal cities of the kingdom. The origins of this legislation have never been seriously analysed; they appear to lay within the increasing fears of the 'dangerous classes', the belief among the Liberals that an alternative was needed to the Carabinieri, which appeared to them to be controlled by aristocratic conservatives, and that such an alternative was to be found in a civilian police somewhat along the lines of the English Bobby. With the unification process of the $1860 \mathrm{~s}$ both the Carabinieri and the Guardia di Pubblica Sicurezza spread down the peninsula. Unfortunately for the P.S., the differentiation of the roles of the two forces was never clarified and it tended to take second place to the elite, glamorous troops of the Carabinieri whose battle honours included some key clashes in the wars of unification $^{25}$.

Members of the Italian Parliament during the 1860 s professed admiration for the English Bobby, but were reluctant to let policing pass out of the hands of the state

24 «Les sbires sont des brigands privilégiés qui font la guerre a des brigands qui ne sont pas privilégiés.» Quotation in Madelin (1906, p. 67); and for the sbirri see Hughes (1987).

25 Hughes (1996). 
and into those of the municipalities. The Parliamentary Committee which met in December 1861 to determine whether or not the P.S. should be spread across the new kingdom concluded that, unfortunately, the Italians were not yet ready to take responsibility for policing themselves. However, Italian cities had long traditions of independence and civic pride. During the revolutions of 1848 several had experimented with municipal civilian police based on their perception of the English model, and, with the liberal freedoms of the early 1860 s, they experimented again. The big cities, particularly in the north, established their own Guardie Municipali. Again these are forces which have never been the subject of detailed academic investigation. However, at least as late as the 1880 s, local authorities in Italy appear to have considered their own municipal and forest guards, local men responsible to local government, as superior to the P.S. - generally, it would seem, underfunded, understrength, overage, and disparaged as sbirri - and often as preferable to the Carabinieri ${ }^{26}$.

Just as Piedmont was not Italy, though it played the central role in unification, so Prussia was not Germany, and played a key role in unification. In Prussia too, the same three varieties of police existed during the nineteenth century, and developed differently because of the different context. A Gendarmerie was created in 1812 as part and parcel of the modernising reforms introduced in the wake of the disasters of 1806 and 1807; but the legal and administrative reforms of which it was part were vigorously resisted by the Junkers who saw these changes as a threat to their personal authority and particularly the concept of Herrschaft which defined their relationship with the peasantry under their jurisdiction. The administrative reforms which constituted a major element of the Gendarmerie Edict of 1812 were never introduced; the Gendarmerie itself survived, but in greatly reduced numbers. In the first half of the nineteenth century Prussia's rulers commonly considered that their first line of defence against serious disorder was the army ${ }^{27}$.

State civilian police, similar to the system functioning under the lieutenant général in Paris, had begun to be developed in the mid-eighteenth century. The Städteordnung of November 1808, which was part of the post Jena reformers' programme of modernisation, made provision for popular representation in town government and the election of officials, but it also declared that policing was a Crown prerogative. Thus, while municipal policemen might be administered by the town council, they acted as representatives of the king. This tended to make the urban elites reluctant to improve their policing structures as they felt that they were paying for men who were under central direction and, as in Italy, it encouraged Liberals to look with interest on the alternative models which were developing in Britain that were both civilian and municipal. The Revolutions of 1848 saw Prussian Liberals experimenting along the lines of the British Bobby, most notably in Berlin. The Police Law of 1850 however, introduced in a reactionary atmosphere, sought to ensure that urban police remained state police; a police director was to be appointed for the principal municipalities by the central government, but all of the costs of his men, their buildings, and equipment were to be met by the municipality. Infuriated at having to pay for policemen over whom they had no control, the municipalities

\footnotetext{
26 Davis (1989, p. 232-233 and 237-241); Jensen (1989); Hughes (1996).

27 The following discussion draws on Kosselleck (1975); Funk (1986); Lüdtke (1989); Jessen (1991); Reinke (1991); Spencer (1992).
} 
took the state to court over the financial provisions of the law, and won. The rulers of the Prussian state concluded that they could not afford to pay for the police of all provincial cities as well as that of Berlin and, consequently, decided on the removal of all but eleven of the police directorships. This upshot was that the state civilian police were transformed back into municipal police.

The municipal police (Kommunale Ortspolizeibehörde) which emerged in Prussian towns and cities during the early 1860 s were technically under the authority of the central state since, constitutionally - and in keeping with the 1808 Städteordnung - no police authority was ever devolved to local government. Theoretically the government in Berlin could have chosen to intervene in matters of municipal policing, but in practice it very rarely attempted to do so, recognising that any such action might provoke constitutional debate and political difficulties with the big cities. The municipalities made most of their own decisions regarding their police structures and organisation, and they issued police ordinances for the regulation of local matters; but there were problems. The most acute of these appear to have been experienced in the burgeoning, turbulent industrial 'wild west' towns of the Ruhr. In the decade or so immediately before World War One the virtues of state civilian, as opposed to municipal civilian, police began again to be debated. The Royal Prussian Police (Königliche Schutzmannschaft) were seen increasingly to be preferable; they seemed better disciplined, without the potential problem of local ties, more able to maintain surveillance of political organisations and to pursue offenders outside the district in which they served. All of this suited both officials in Berlin and the respectable Rhineland burghers; the latter's Heimat had now been incorporated into Prussia for almost a century and, for a variety of reasons, the respectable Rhinelanders were identifying themselves more and more with that state. Equally important to the cost-conscious Rhineland burgher, the Royal Police were cheaper since they were funded from the state treasury rather than local coffers; the police finance law of 1908 made the state treasury responsible for twothirds of the funding of Royal Schtzmannschaften, the remaining third came from the towns and cities where they were established ${ }^{28}$. Significantly the years immediately before the war witnessed the Royal Police moving into the Ruhr and the Upper Silesian coalfields. Yet even here some local municipal police remained responsible for the supervision of markets, certain trades, master-servant relations, school attendance, public health, and the streets.

The experience of Italy and Germany suggests that, even in territories that were aggressively unified or dominated by an absolutist, militarist structure, police development was never simply dictated or dominated from the centre. There was always negotiation between central government and the localities; on both sides there were considerations of independence as well as of cost. Other models were looked to ${ }^{29}$, borrowed from, and reshaped to take account of different cultural

28 The Städteordnung of 1808 , the continuance of the Prussian Gendarmerie after 1820, and finally the spread of the Royal Police suggests that Bayley's assertion $(1985$, p. 71) that in Prussia «policing remained decentralized $»$ is in need of some qualification.

29 The Minghetti Papers in the Biblioteca comunale di Bologna contain a large number of different documents forwarded by the London Metropolitan Police as examples of how it was organised and functioned. My thanks to Steven Hughes for this information (personal communication 25 May 1991). Requests for information from different German states appear to have been such that from the summer of 1878 the Criminal Investigation Department, at least, of the Metropolitan Police had note-paper headed in German - Polizei-Behörde in London, Abtheilung für Criminal-Sachen; see, 
perspectives and perceptions. Yet overall, it would probably be true to say that across nineteenth-century Europe the role of the central state in policing, as in many other areas, was becoming more significant.

\section{IV}

The nineteenth-century state was increasingly jealous of its authority. Where local elites could be depended upon and/or where they were indistinguishable from the national elite, shared agreement about the constitutional structure, and where no serious threat was posed to the state's legitimacy, then civilian, municipal police were allowed to flourish. Yet it would be wrong to assume from this that the creation of a state civilian or state military police depended solely on the will of even the most authoritarian government. In the early nineteenth century the government at Westminster was able to impose a gendarmerie system on the Irish gentry; that government was strong, confident, successful but, by the standards of the time, not particularly authoritarian; while the Irish gentry had a poor record of exercising its authority and maintaining order, and no particular clout in parliament. In contrast, reformers in Prussia were seeking to revive an enfeebled state with impoverished coffers; they were unable to press forward with their plans for a Gendarmerie and a restructuring of the legal system in the way that they had hoped because they faced a challenge from an articulate and powerful gentry, intensely loyal to the king but intensely hostile to those who seemed to be set on destroying that gentry's way of life and relationship with its peasantry.

Nineteenth-century states did not, of course, exist in individual vacuums but side-by-side observing each other's developments sometimes seeking to emulate, sometimes seeking to avoid the experience or practice of a neighbour. In the case of police developments they borrowed models and shaped them to their own needs, but also saw the models shaped by their own varying contexts. And while this essay has been at pains to stress three types of nineteenth-century policing, it would be wrong to assume that each of these types existed in every state. The Scandinavian countries did not employ state military police for internal duties with the exception of Denmark, where a Gendarmerie was established in the suspect province of Schleswig in 1851, and where a nervous government of the right established such a corps to police the whole country between 1885 and $1894^{30}$. It was only in John Bull's other island and in the British Empire that gendarmerie-style police were deployed as a rule by the government at Westminster. English sensibilities were such that an overtly military police probably could never have been created in England itself even had the government so wished. Moreover, the very success of the French Gendarmerie coupled with the suspicion of things French and British success in the wars against the Revolution and Napoleon, were probably important contributory elements in the search for something different when it came to estab-

for example, correspondence in Brandenburgisches Landeshauptarchiv, Orangerie, Potsdam, Pr.Br.

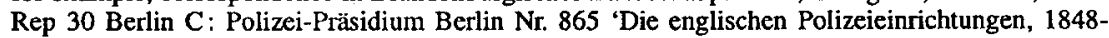
$1882^{\prime}$. My thanks to Carl Wade for this reference.

My thanks to Gunner Lind for this information (personal communication 20 Oct. 1997). 
lishing the Metropolitan Police ${ }^{31}$. Like the Liberals of continental Europe, reformers from the big cities of the eastern seaboard of the United States also looked to the English Metropolitan Police model, though the system of control was much closer to that of the borough watch committees. Here too there were suspicions of soldiers on the streets. Furthermore the federal structure and democratic ideology of the United States militated against the creation of any significant police organisation run from Washington; it was the democratic ideology in particular which ensured the predominance of different varieties of civilian municipal police.

The three types discussed here are essentially concerned with accountability, control and form, rather than function. It would, of course, be possible to construct another series of types based on function which crossed the boundaries of the types delineated here. Detective police were generally civilian as opposed to military; political surveillance was a state police task, both military and civilian, as opposed to municipal. Furthermore, the savoir-faire developed by policemen in particular functions would probably have made the tasks and work practices of, for example, a Bulle in the Hamburg docks district perfectly understandable to, and perhaps interchangeable with those of a Peeler in the Liverpool docks district, and similarly with say, a gendarme patrolling the Aveyron and a Bobby in the North Riding of Yorkshire.

This leads on to two important questions with which I wish to conclude as suggestions for further thought and further research. It was not just at the level of the man on daily patrol that, during the nineteenth century, the police began to develop a kind of professional savoir-faire. Max Weber suggested that the growth of bureaucracy could lead to the professional, by virtue of his role, seeking to gain autonomy over his political masters who, in comparison with the bureaucratic expert, increasingly seemed dilettantes ${ }^{32}$. This may be an important way into an exploration of the way that links were strengthened between the professional police of municipalities and the state bureaucrats at least in Britain and France at the end of the nineteenth and beginning of the twentieth centuries. But if this was the case at municipal level, may there not also have been some similar developments at state level? The study of nineteenth-century policing is now fairly well developed, but work on the twentieth century is lacking and an exploration of autonomy at the level of senior police officers and state bureaucrats might be one item for the agenda. Secondly, if typologies at the level of control, form, and functions were similar, there is a need to explore the roots of police behaviour and perceptions of that behaviour in both national and comparative contexts. The policemen of Victorian England used violence, sometimes indiscriminately and excessively ${ }^{33}$, but by both English and European commentators, they were not perceived to be as violent as American cops, French flics, or German Bulles. Possibly this was indeed the case, but it needs exploration rather than assertion; furthermore, it may be less because of anything

31 In emergencies such as the Rebecca riots in South Wales in 1839 or the strikes in the years before World War One, English police could be supported by, and act alongside soldiers. This might have led to them ressembling state military police, yet they always remained quite separate and distinct from the army. Moreover, in France and Italy, gendarmes or carabinieri confronting strikes or other large popular manifestations could similarly be seconded by conventional soldiers.

32 Weber (1968, III, p. 991).

33 Emsley (1985). 
structural within the English police, and rather more because of something structural in English society which made it, as a whole, less violent.

\author{
Clive Emsley \\ The Open University \\ Walton Hall \\ Milton Keynes MK7 6AA \\ UK \\ E-mail: c.emsley@open.ac.uk
}

\title{
REFERENCES
}

Ascoli, D., The Queen's Peace: The Origins and Development of the Metropolitan Police, 1829-1979, London, Hamish Hamilton, 1979.

Axtmann, R., «Police» and the formation of the modern state. Legal and ideological assumptions on State capacity in the Austrian Lands of the Habsburg Empire, 1500-1800, German History, 1992, 10, p. 39-61.

Bayley, D.H., The police and political development in Europe, in Tilly, C., (Ed.), The Formation of the National States in Western Europe, Princeton, N.J., Princeton University Press, 1975.

Bayley, D., Patterns of Policing. A Comparative International Analysis, New Brunswick, N.J., Rutgers University Press, 1985.

Berlière, J.M., Le préfet Lépine. Vers la naissance de la police moderne, Paris Denoël, 1993.

Davis, J.A., Conflict and Control. Law and Order in Ninetenth-Century Italy, London, Macmillan, 1989.

Emsley, C., Policing and its Context, 1750-1870, London, Macmillan, 1983.

Emsley, C., «The thump of wood on a swede turnip». Police violence in nineteenth-century England», Criminal Justice History, 1985, VI, p. 125-49.

Emsley, C., 'The English Bobby: an indulgent tradition', in Porter, R., (Ed.), Myths of the English, Oxford, Polity Press, 1992.

Emsley, C., The English Police: A Political and Social History, London, Longman, 1996, (2nd. edn.).

Emsley, C., Gendarmes and the State in Nineteenth Century Europe, Oxford, Clarendon Press, 1999.

Funk, A., Polizei und Rechtsstaat: Die Entwicklung des staatlichen Gewaltmonopols in Preussen 1848-1914, Frankfurt, Campus, 1986.

Gaveau, F, L'ordre aux champs. Pour une histoire des gardes champêtres 1789-1880, Mémoire de DEA d'histoire, Dijon, Université de Bourgogne, 1997.

Hauterive, E. d', (Ed.), La police secrète du Premier Empire, 5 vols, Paris, Perrin (later Clavreuil), 1922-1964.

Hjellemo, O., A tribute to an unusual historian of police: Charles Edward Williams Reith (1886-1957), Police College Magazine, 1977, 14, p. 5-8.

Hughes, S.C., Fear and loathing in Bologna and Rome. The papal police in perspective, Journal of Social History, 1987, 21, p. 97-116.

Hughes, S.C., Poliziotti, Carabinieri e «Policemen»: il bobby inglese nella polizia italiana, La Carta e la Storia, 1996, 11, p. 22-31.

Jensen, R.B., Police reform and social reform: Italy from the crisis of the 1890 s to the Giolittian era, Criminal Justice History, 1989, 10, p. 179-200. 
Jessen, R., Polizei im Industrierevier: Modernisierung und Herrschaftspraxis im westfälischen Ruhrgebiet, 1848-1914, Göttingen, Vandenhoeck \& Ruprecht, 1991.

Kosselleck, R., Preussen zwischen Reform und Revolution: Allgemeines Landrecht, Verwaltung und Sozialbewegung von 1791 bis 1848, Stuttgart, Emst Klett, 1975 (2 edn.).

Lowe, W.J., Malcolm, E.L., The domestication of the Royal Irish Constabulary, 1836-1922, Irish Economic and Social History, 1992, XIX, p. 27-48.

Lüdtke, A., Police and State in Prussia, 1815-1850, Cambridge, Cambridge University Press, 1989.

Madelin, L., La Rome de Napoléon. La domination française à Rome de 1809 à 1814, Plon, Paris, 1906.

Palmer, S.H. Police and Protest in England and Ireland 1780-1850, Cambridge, Cambridge University Press, 1989.

Pike, L.O., A History of Crime in England, 2 vols, London, Smith, Elder and Co., 1873-1876.

Raeff, M., The Well-Ordered Police State: Social and Institutional Change Through Law in the Germanies and Russia, 1600-1800, New Haven, Yale University Press, 1983.

Reinke, H., «Armed as if for a war»: The state, the military and the professionalisation of the Prussian Police in Imperial Germany, in Emsley, C., Weinberger, B., (eds.), Policing Western Europe: Politics, Professionalism and Public Order, 1850-1940, New York, Greenwood Press, 1991, p. 55-73.

Reiner, R., The Politics of the Police, Brighton, Wheatsheaf, 1985.

Reith, C., The Police Idea, Oxford, Oxford University Press, 1938.

Reith, C., Police Principles and the Problem of War, Oxford, Oxford University Press, 1940.

Reith, C., British Police and the Democratic Ideal, Oxford, Oxford University Press, 1943.

Reith, C., A Short History of Police, Oxford, Oxford University Press, 1948.

Reith, C., The Blind Eye of History, London, Faber, 1952.

Santucci, M.R., Délinquance et répression au XIX siècle. L'exemple de l'Hérault, Paris, Économica, 1986.

Soulet, J.F., Les Pyrénées au XIX' siècle, 2 vols, Toulouse, Éche, 1987.

Spencer, E.G., Police and the Social Order in German Cities. The Diisseldorf District 18481914, De Kalb, Northern Illinois University Press, 1992.

Tulard, J., Paris et son administration (1800-1830), Paris, Ville de Paris, Commission des Travaux Publics, 1976.

Vogel, M.T., Les polices des villes entre local et national: l'administration des polices urbaines sous la III République, Doctorat de science politique, 3 vols, Université de Grenoble II, 1993.

Weber, M., Economy and Society. An Outline of Interpretive Sociology, 3 vols. New York, Bedminster Press, 1968.

Woloch, I., The New Regime. Transformations of the French Civic Culture 1789-1820s, New York, Norton, 1994. 